\title{
Human reproductive system disturbances and pesticide exposure in Brazil
}

\author{
Distúrbios do sistema reprodutivo humano \\ e exposição a pesticidas no Brasil
}

\begin{abstract}
Sergio Koifman 1
Rosalina Jorge Koifman 1

Armando Meyer 1
\end{abstract}

\footnotetext{
1 Departamento de

Epidemiologia e Métodos Quantitativos em Saúde, Escola Nacional de Saúde Pública, Fundação Oswaldo Cruz.

Rua Leopoldo Bulhoes 1480, Rio de Janeiro, $R J$ 21041-210, Brasil. koifman@ensp.fiocruz.br
}

\begin{abstract}
The observation of reproductive disturbances in humans and in the wildlife has been reported in the last decade in different countries. Exposure to different chemicals possibly acting in the endocrine system or endocrine disruptors, including pesticides, has been a hypothesis raised to explain the observed changes. This paper aimed to present results of an epidemiological ecologic study carried out to explore population data on pesticides exposure in selected Brazilian states in the eighties and human reproductive outcomes in the nineties. Pearson correlation coefficients were ascertained between available data pesticides sales in eleven states in Brazil in 1985 and selected further reproductive outcomes or their surrogates. Moderate to high correlations were observed to infertility, testis, breast, prostate and ovarian cancer mortality. Despite the restrains of ecologic studies to establish cause-effect relationships, the observed results are in agreement with evidence supporting a possible association between pesticides exposure and the analyzed reproductive outcomes.
\end{abstract}

Key words Factor Analysis, Statistical; Pesticides; Infertility; Neoplasms; Endocrine Disruptors

Resumo A observação de distúrbios reprodutivos em seres humanos e na vida animal tem sido relatada em diferentes países na última década, sendo apontada como possível explicação para tal fenômeno, a exposição a diversas substâncias químicas com possível interferência no sistema endócrino, incluindo pesticidas. Este trabalho apresenta os resultados de um estudo epidemiológico, com delineamento ecológico explorando dados de exposição a pesticidas durante os anos oitenta, em estados brasileiros selecionados e distúrbios reprodutivos observados nos anos noventa. Foram obtidos coeficientes de correlação de Pearson entre o volume de vendas de pesticidas em onze estados brasileiros em 1985 e indicadores diretos ou substitutos da ocorrência de distúrbios reprodutivos nas mesmas localidades. Coeficientes de correlação moderados e elevados foram observados para a maioria dos indicadores dos desfechos analisados; infertilidade e câncer do testículo, mama, próstata e ovário. Apesar das limitações inerentes aos estudos ecológicos quanto ao estabelecimento de relações de causa-efeito, os resultados observados estão em concordância com as evidências, apoiando uma possível associação entre a exposição a pesticidas e os distúrbios reprodutivos analisados.

Palavras-chave Análise Fatorial; Praguicidas; Infertilidade; Neoplasias; Desreguladores Endócrinos 


\section{Introduction}

Exposure to chemical substances displaying a hormonal-like molecular structure, generally named endocrine disruptors, has been gathering scientific interest as a consequence of the observed association with several biological hazards in humans and animals (Al-Omar et al., 2000; Carlsen et al., 1992, 1993; Chapin et al., 1996; Joffe, 2001; Safe, 2000; Scharpe, 2001). Several disturbances such as changes in sex ratio, sperm physical properties, increase of abortion rates, birth defects, cancer distribution at selected reproductive system sites and development of a female phenotype by wildlife species have been reported in the literature during the last decades, including the occupational set (Fleming et al., 1999; Padungtod et al., 1998; Restrepo et al., 1990a, 1990b; Wiklund et al., 1989; Zahm \& Blair, 1993). Nevertheless, achievement of a comprehensive and conclusive evidence frame linking endocrine disruptors exposure and these outcomes remain unclear (Chia, 2000; Gray, 1998; Irvine, 2000; Monosson et al., 1999; Petrelli et al., 2000).

Among the reported reproductive changes, the following could be highlighted in brief: the observed decline along time in the ratio of male to female individuals (sex ratio) in some countries; the changes in sperm characteristics such as lower count and decreased motility reported in animals and humans (Jones \& Cooper, 1999; Lahdetie, 1995); the occurrence of selected birth defects such as cryptorchidism (prenatal incomplete or absent testis descent from the abdominal cavity to scrotum) and hypospadia (postnatal persistence of a penis opening following incomplete urogenital sinus closure)in the male newborn (Clegg et al., 1999); the observed evidence on the association between cryptorchidism and the subsequent development of infertility and testicular cancer (Chilvers et al., 1986; Henriksen et al., 1996); the reported changes on fertility patterns among both gender in young population strata (Glass et al., 1979); and the controversial association between testis, breast, ovarian and prostate cancer distribution related to longtime exposure to such hormonal-like chemicals (Bullman et al., 1994; Dolapsakis et al., 2001; Mills, 1998; Putnam et al., 2000; Stellman et al., 1998; Weir et al., 2000).

Whether the scope of reproductive outcomes is wide, it is also the list of theoretically involved risk factors, including previously used drugs, such diethylestilbestrol (DES) and formerly used pesticides, such as 1,1,1-trichloro2,2-bis(4-chloro-phenil)ethane (DDT) and di- bromochloropropane (DBCP), all banned after longtime exposure and several subsequent adverse outcomes following their use (Ekbom et al., 1996; Goldsmith, 1997; Potashnik \& Porath, 1995; Rodriguez \& Bustos-Obregon, 2000; Saracci et al., 1991; Teitelbaum, 1999).

However, several other chemical compounds with acknowledged endocrine disrupting activity, mainly pesticides, remain legally or illegally in use in different countries, including Brazil. Some of them, such as certain insecticides $(\beta-\mathrm{HCH}$, carbaril, chlordane, dieldrin, endosulfan, hepthaclor), herbicides (amitrole, iatrazin, nitrofen, metribuzin), fungicides (hexaclorbenzene, metiran) and nematicides (DBCP, aldicarb), have been reported to display endocrine disrupting properties (Colborn, 1993; Wesseling et al., 1999).

Moreover, pesticides sales more than doubled in Brazil during the last decade, rising from US\$ 980,509.00 in 1989 to US\$2,346,539.00 in 1999 (MAPA, 2000), mainly related to herbicides and insecticide sales (Figure 1). Probably besides non compliance to safe management standards, mainly among low educated farmers, the distribution of acute and chronicle effects either on direct users (farmers, public health workers, and others) or in the general population remain unknown in the country.

This study aimed to join evidence on the possible correlation between pesticides exposure in the mid 80's and selected reproductive system disturbances further reported a decade later by the national health system in Brazil.

\section{Methods}

An epidemiological ecological study was carried out by comparing the total amount of pesticides sales (tons) in 1985 (Garcia \& Almeida, 1991), used as a surrogate of population exposure to such chemicals relative to selected Brazilian States (São Paulo, Paraná, Santa Catarina, Rio Grande do Sul, Bahia, Pernambuco, Espírito Santo, Minas Gerais, Mato Grosso, Mato Grosso do Sul and Goiás, in which this information was available), and selected health outcome data traced in the same States towards the Brazilian National Health Data System (DATASUS), which displays information on mortality, hospitalization authorizations, health procedures, and several others.

To estimate infertility levels prevalent in these populations, we obtained data on the amount of selected procedures adopted to investigate infertility between October 1, 1999 and September 30, 2000. They were sperm eval- 


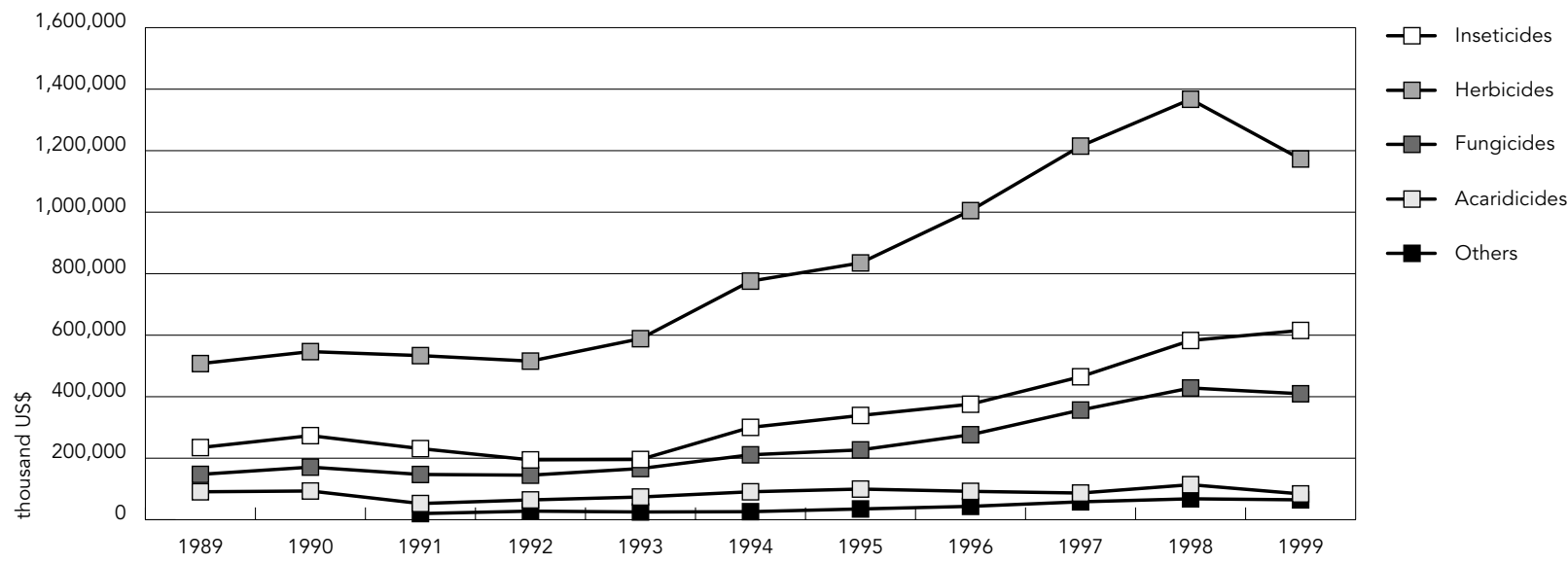

uations on the male partner (spermiogram), including the analysis of sperm physical characteristics, sperm count, sperm motility, and sperm morphological anomalies (procedure code 1102103), and histerosalpingography in the female partner, a radiological procedure to evaluate uterine and tube obstruction or any other abnormality (procedure code 1310503), both usually requested as the first step to clinically launch an infertility investigation. Later, State-specific sperm evaluation rates among men 20-59 yr. and histerosalpingography rates among 20-49 yr. women were obtained.

Post natal undescended testis (cryptorchidism) correction surgeries (orchidopexy) carried out in these states were used to estimate such condition rates using specific 0-9 yr. populations as denominators. In the same way, authorizations for testicular cancer chemotherapy (procedures code 2915101 and 2915103) were ascertained, and used to estimate testis cancer incidence towards obtaining testicular cancer chemotherapy rates in the aforementioned States.

Testicular cancer hospitalizations in these regions were ascertained and age specific visitation rates (0-14 and 15-49 yr.) were determined, taking into account the total amount of hospitalizations and the age related populations, considering a yearly average of two hospitalizations per patient. Further, spermiogram and testicular cancer hospitalization rates were also ascertained in selected municipalities in the States of Rio Grande do Sul and São Paulo, which seems to display a high magnitude of reproductive hazards in Brazil.

Testis, prostate, female breast and ovarian cancer mortality rates at specific age strata and age adjusted overall rates were obtained in the same States during 1996-1998, with data provided by the National Mortality System and census population estimates.

Pearson's correlation coefficients and determination coefficients were then obtained for pesticide sales and the following reproductive malfunction indicators in the eleven analyzed states: sperm evaluation rates, histerosalpingography rates, cryptorchidism rates, testicular cancer chemotherapy rates, testicular cancer mortality rates, prostate cancer mortality rates, female breast cancer mortality rates and ovarian cancer mortality rates.

Finally, a principal component analysis and a factor analysis using varimax and equamax rotation were carried out aiming to explore the relationships between the analyzed indicators.

\section{Results}

The ascertained reproductive outcome rates in selected Brazilian States are presented at Table 1 , showing a balanced distribution of histerosalpyngography rates, but a large variability according to orchidopexy and testicular cancer hospitalization rates, mainly among adults. Pesticide sales in 1985 and age adjusted mor- 
Table 1

Reproductive hazard indicators rates. Selected states, Brazil.

\begin{tabular}{|c|c|c|c|c|c|c|}
\hline State & Sperm counta & Histerosalpingographyb & Orchidopexyc & $\begin{array}{l}\text { Testicular cancer } \\
\text { chemotherapyd }\end{array}$ & $\begin{array}{c}\text { Testicular cancer } \\
\text { hospitalization } \\
(0-14 \text { yr.)e }\end{array}$ & $\begin{array}{c}\text { Testicular cancer } \\
\text { hospitalization } \\
(15-49 \text { yr. })^{f}\end{array}$ \\
\hline Minas Gerais & 201.3 & 45.6 & 75.9 & 2.2 & 0.3 & 0.8 \\
\hline Mato Grosso do Sul & 52.3 & 41.6 & 11.8 & 0.8 & 0.3 & 0.5 \\
\hline Mato Grosso & 66.4 & 28.9 & 16.3 & 1.9 & 0.3 & 1.4 \\
\hline Goiás & 132.4 & 30.6 & 42.1 & 2.5 & 0.2 & 0.6 \\
\hline Espírito Santo & 114.2 & 61.8 & 30.0 & 1.4 & 0.3 & 1.0 \\
\hline Bahia & 87.5 & 7.7 & 17.1 & 0.2 & 0.2 & 0.5 \\
\hline Rio Grande do Sul & 93.9 & 56.9 & 45.1 & 4.1 & 0.9 & 6.4 \\
\hline São Paulo & 261.4 & 47.0 & 41.7 & 2.5 & 0.6 & 1.5 \\
\hline Paraná & 115.2 & 49.3 & 51.9 & 4.6 & 0.9 & 2.4 \\
\hline Santa Catarina & 221.0 & 66.1 & 49.9 & 5.0 & 0.9 & 1.9 \\
\hline Pernambuco & 83.7 & 41.2 & 9.1 & 1.3 & 0.1 & 0.3 \\
\hline
\end{tabular}

a Spermiogram performed rates (per 100,000), men 20-59 yr., October 1999 - September 2000.

b Histerosalpingography performed rates (per 100,000), women 20-49 yr., October 1999-September 2000.

c Orchidopexy rates, men 0-9 yr. (per 100,000),1988-1990.

d Testicular cancer chemotherapy rates (100,000 men), October 1999 - September 2000.

e Estimated testicular cancer (0-14 yr.) hospitalization rates per 100,000 (2 hospitalizations per year in average), $1995-1997$.

$\mathrm{f}$ Estimated testicular cancer (15-49 yr.) hospitalization rates per 100,000 (2 hospitalizations per year in average), $1995-1997$.

tality rates of selected hormonal related cancer sites in 1996-1998 are displayed at Table 2.

Moderate to high Pearson's correlation coefficients ranging from 0.36 to 0.81 were observed among pesticides sales in eleven states in 1985 and further reproductive hazards during the nineties (Table 3). Statistically significant correlations were seen for breast cancer mortality among women 50-69 yr. during 19951997 ( $\mathrm{r}=0.81,0.41-0.95)$, women $40-49$ yr. ( $\mathrm{r}=$ $0.66,0.10-0.90)$, ovarian cancer mortality $(\mathrm{r}=$ $0.71,0.19-0.92$ ), and a borderline result for sperm evaluation rates $(\mathrm{r}=0.60,-00.1-0.88)$.

Non statistically significant correlations were observed among pesticide sales and prostate mortality rates $(\mathrm{r}=0.67)$, testicular cancer mortality rates $(r=0.53)$, testicular cancer chemotherapy rates $(r=0.36)$, testicular cancer hospitalization rates $(r=0.36$ among men 0 - 14 yr. and $r=0.39$ at $15-49$ yr.) and orchidopexy (cryptorchidism correction surgery) rates $(r=0.41)$. A low statistically non significant correlation was seen for histerosalpingography performed rates and pesticide sales $(\mathrm{r}=$ $0.18)$.

Elevated testicular cancer hospitalization rates among men 15-49 yr. old were observed in the states of Rio Grande do Sul, Paraná and Santa Catarina, being particularly high in the former. A more detailed analysis of the geographical distribution of such indicators could identify some countryside municipalities such as Santa Maria, Passo Fundo, Santa Cruz do Sul, Santa Rosa, Uruguaiana, among others, displaying elevated testicular hospitalization rates during 1995-1997. High sperm evaluation rates were also observed in some of these same municipalities (Table 4).

Moderate to high correlations were observed for the majority of studied variables (correlation matrix not presented). The KaiserMeyer Olkim measure of sampling adequacy was 0.51 and Bartlett's test of sphericity showed a chi square value of 72.27 (36 degrees of freedom, $\mathrm{p}<0.0001)$. Principal components analysis revealed that $74.3 \%$ of the total variance was explained by the first two components $(59.2 \%$ by the first alone). The rotated component matrix (varimax rotation) showed high factor loadings at the first component for the variables testicular cancer hospitalizations, testicular cancer chemotherapy, breast cancer mortality, ovarian cancer mortality, and moderate loadings for pesticides sales and histerosalpingography performed rates (Table 5). On the other hand, the second component displayed high factor loadings for pesticides sales, sperm evaluation rates and orchidopexy rates (Table 5 ; Figure 2). Equamax rotation (results not presented) showed quite similar results obtained with varimax rotation relative to both first components, but revealed a more balanced distribution of pesticide sales factor loadings, respectively, 0.58 and 0.51 . 
Pesticides sales (1985) and age adjusted prostate, female breast and ovarian cancer mortality rates (1996-1998).

Selected states, Brazil.

\begin{tabular}{|c|c|c|c|c|c|}
\hline State & $\begin{array}{c}\text { Pesticide } \\
\text { sales (tons)a }\end{array}$ & Prostate cancer & Testicular cancer & Breast cancer & Ovarian cancer \\
\hline Minas Gerais & 12,308 & 11.3 & 0.2 & 9.3 & 3.5 \\
\hline Mato Grosso do Sul & 4,240 & 13.5 & 0.1 & 8.3 & 3.0 \\
\hline Mato Grosso & 2,000 & 10.8 & 0.1 & 7.3 & 1.5 \\
\hline Goiás & 3,386 & 12.2 & 0.2 & 8.8 & 2.2 \\
\hline Espírito Santo & 771 & 12.2 & 0.2 & 8.7 & 3.2 \\
\hline Bahia & 8,348 & 7.6 & 0.1 & 5.7 & 2.7 \\
\hline Rio Grande do Sul & 20,800 & 17.2 & 0.6 & 15.5 & 6.4 \\
\hline São Paulo & 43,991 & 16.3 & 0.3 & 16.0 & 6.4 \\
\hline Paraná & 21,672 & 15.1 & 0.4 & 11.6 & 4.0 \\
\hline Santa Catarina & 6,430 & 12.7 & 0.5 & 11.6 & 5.4 \\
\hline Pernambuco & 1,300 & 10.1 & 0.1 & 9.3 & 3.9 \\
\hline
\end{tabular}

Source: Garcia \& Almeida, 1991.

a Mortality rates (1996-1998) per 100,000 adjusted by the world population (Segi, 1960).

Table 3

Pearson's correlation and determination coefficients among pesticides sales (1985) and selected reproductive health indicators (90's). Selected states, Brazil.

\begin{tabular}{|c|c|c|c|}
\hline \multirow[t]{2}{*}{ Health indicator } & \multicolumn{2}{|c|}{ Pearson's coefficient } & \multirow{2}{*}{$\begin{array}{c}\text { Determination } \\
\text { coefficient } \\
r^{2}\end{array}$} \\
\hline & r & $95 \% \mathrm{Cl}$ & \\
\hline Spermiogram rates (1999-2000) & 0.60 & $-0.31-0.79$ & 0.35 \\
\hline Histerosalpingography rates (1999-2000) & 0.21 & $-0.58-0.62$ & 0.05 \\
\hline Cryptorchidism rates (1988-1990) & 0.41 & $-0.48-0.70$ & 0.17 \\
\hline Testicular cancer chemotherapy rates (1999-2000) & 0.36 & $-0.51-0.68$ & 0.13 \\
\hline \multicolumn{4}{|l|}{ Testicular cancer hospitalizations (1995-1997) } \\
\hline $0-14$ yr. & 0.46 & $-0.44-0.72$ & 0.21 \\
\hline $15-40 \mathrm{yr}$ & 0.39 & $-0.49-0.69$ & 0.15 \\
\hline \multicolumn{4}{|l|}{ Breast cancer mortality (1995-1997) } \\
\hline $20-39$ yr. & 0.39 & $-0.49-0.69$ & 0.15 \\
\hline $40-49$ yr. & 0.66 & $-0.22-0.82$ & .044 \\
\hline $50-69$ yr. & 0.81 & 0.09-0.90 & 0.65 \\
\hline All ages (1996-1998) & 0.80 & $0.06-0.90$ & 0.64 \\
\hline Ovarian cancer mortality (1995-1997) & 0.71 & $-0.14-0.85$ & 0.51 \\
\hline Testicular cancer mortality (1996-1998) & 0.53 & $-0.39-0.75$ & 0.28 \\
\hline Prostate cancer mortality (1996-1998) & 0.67 & $-0.20-0.83$ & 0.45 \\
\hline
\end{tabular}


Sperm evaluation rates (October 1999 to September 2000) and testicular cancer hospitalization rates (1993-1997), men 15-59 yr. Selected municipalities, Rio Grande do Sul State, Brazil.

\begin{tabular}{lcll}
\hline Municipality & $\begin{array}{c}\text { Spermiogram } \\
\text { rates }\end{array}$ & $\begin{array}{c}\text { Testis cancer } \\
\text { hospitalization rates }\end{array}$ & Main economic activity \\
\hline Soledade & 524.8 & 3.6 & Corn, wheat, cattle \\
Porto Alegre & 352.2 & 32.7 & Several \\
Passo Fundo & 270.8 & 13.5 & Wheat, cattle, food \& wood industries \\
Santa Rosa & 245.7 & 5.6 & Corn, soy, yucca, cattle \\
Santa Cruz do Sul & 169.1 & 5.2 & Tobacco farms, cattle \\
Pelotas & 153.3 & 5.4 & Several industries, cattle \\
Santa Maria & 123.3 & 20.8 & Cattle \\
Novo Hamburgo & 102.0 & 4.4 & Leather, metallurgy, textile industry \\
Uruguaiana & 100.4 & 5.2 & Wheat, rice, cattle, meat industry \\
Vacaria & 92.1 & 3.0 & Cattle, wheat, food \& wood industries \\
ljuí & 75.4 & 5.0 & Cattle, soy, wheat, food industry \\
Bagé & 59.0 & 5.1 & Wheat, cattle, food, chemicals
\end{tabular}

Estimated rates per 100,000 men (15-59 yr.).

* Estimated average of two hospitalizations per patient per year, 1995-1997.

\section{Discussion}

Data availability on the general amount of pesticides sales in many states in Brazil during the eighties enabled us to organize an exploratory analysis by comparing, in the same regions, selected reproductive outcomes reported in the literature as associated to such exposure.

However, the ecological approach used in this study has several inherent potential weaknesses able to induce misleading conclusions. At first, all used data are population based and not individual ones, which may lead to ecological fallacy inducing misinterpretation on causal relationships between variables, when they may be not causally related.

Pesticides sales in the different states does not imply their full use in the same region, mainly in these showing a more active economic profile, where they can be bought to be used elsewhere. Economical trade links may lead pesticides, seeds and other agriculture items to be bought, for instance, in the State of São Paulo to be used in certain areas of the States of Paraná, Minas Gerais or Mato Grosso do Sul. We can indeed suppose that such regional interchange may interfere in some way in almost all analyzed regions. Moreover, information on pesticides sales was not available in 1985 for specific types (insecticides, herbicides, fungicides, and others), which would allow us a more detailed evaluation.
The ascertained estimates for the studied reproductive hazards may also be affected by other flaws. Despite the fact that all estimates on medical procedures were determined using official data relatively to area of residence, such information may also not be truly correct. High standard levels observed in several medical centers in some Brazilian states usually attract patients from other regions, which may also have affected our estimates, even considering our strict criteria of just including local residents in our estimates.

Finally, some of the chosen reproductive hazard indicators may present variable validity, in the sense that some of them may display a misleading overview of the studied phenomena. In this sense, prostate cancer mortality rate would not be the first choice indicator to evaluate this disease distribution, since a large proportion of patients die by other causes of death instead of prostate cancer. The same applies to testis cancer mortality, usually displaying high survival whenever earlier diagnosed, and for this reason, both indicators were not further included in the factor analysis.

Cryptorchidism may be underreported as a consequence of lacking a comprehensive physical examination of newborn. Sperm evaluation is usually the first step in infertility research, but also used for other purposes, such as post-vasectomy evaluation; histerosalpingography is a radiological procedure not only 
used in infertility investigation, but also to evaluate other gynecological conditions.

Used numerators to ascertain testicular cancer chemotherapy and hospitalization rates refer to the total amount of authorizations to carry out such events, and not to individual patients. Therefore, some testicular cancer patients may be hospitalized once, meanwhile others twice or more. Hence, estimated rates of specific procedures in different regions may vary to some degree according to local health policies.

Finally, despite the fact that all analyzed health procedures were obtained from the same databank (DATASUS files), it is prudent to take into account that it was originally rather organized to accomplish auditing activities (the payment of governmental authorization of hospitalizations and other health procedures), instead of epidemiological ones. Despite this potential lacking precision, we believe that only the systematic use of such files may try to identify their weaknesses, thus improving the databank.

Even taking into account such preliminary considerations, we observed that pesticides sales in the past (1985) showed some quite important correlation coefficients, in the next decade, with the distribution of selected cancer sites (testis, prostate, breast and ovarian), besides reproductive malfunction indicators, such as sperm evaluation and performed orchidopexies.

According to breast cancer, we observed a high correlation between past exposure to pesticides and age adjusted breast cancer mortality in 1996-1998 $\left(\mathrm{r}=0.80, \mathrm{r}^{2}=0.64\right)$. The highest correlation was observed among women 50-69 yr. ( $\mathrm{r}=0.81$, 95\%CI: 0.41-0.95), and among women 40-49 yr. and 20-39 yr., they were, respectively, 0.66 (95\%CI: $0.10-0.90)$ and 0.39 (95\%CI: 0.0-0.80). Nevertheless, the velocity of increase seems to be equivalent in the older age strata, showing quite similar angular coefficients in the respective regression lines between the logarithms of breast cancer mortality rates and the logarithm of pesticides sales: women $20-39 \mathrm{yr}$. $\beta=0.03$ (95\%CI: $-0.14-0.19$ ); women $40-49$ yr. $\beta=0.12$ (95\%CI: $-0.04-0.27$ ); women 50-69 yr. $\beta=0.14$ (95\%CI: $-0.05-0.32$ )

The increased correlation coefficients according to age strata, likewise the increased linear coefficients (intercepts) of the same regression lines between the logarithms of breast cancer mortality rates at ages 20-39 yr., 40-49 yr., and 50-69 yr. and the logarithms of pesticides sales (respectively $0.27,0.76,0.97$ ), may suggest, besides the age effect on breast cancer
Table 5

Rotated component matrix, varimax rotation.

\begin{tabular}{lcc}
\hline Variable & Component 1 & Component 2 \\
\hline Pesticides sales & 0.37 & 0.70 \\
Testicular cancer hospitalizations & & \\
0-14 yr. & 0.88 & 0.22 \\
15-49 yr. & 0.93 & -0.04 \\
Sperm evaluation rates & 0.05 & 0.97 \\
Orchidopexy rates & 0.28 & 0.74 \\
Testicular chemotherapy rates & 0.75 & 0.38 \\
Histerosalpingography rates & 0.65 & 0.32 \\
Breast cancer mortality & 0.79 & 0.45 \\
Ovarian cancer mortality & 0.71 & 0.54 \\
\hline
\end{tabular}

Figure 2

Factor analysis: component plot in rotated space.

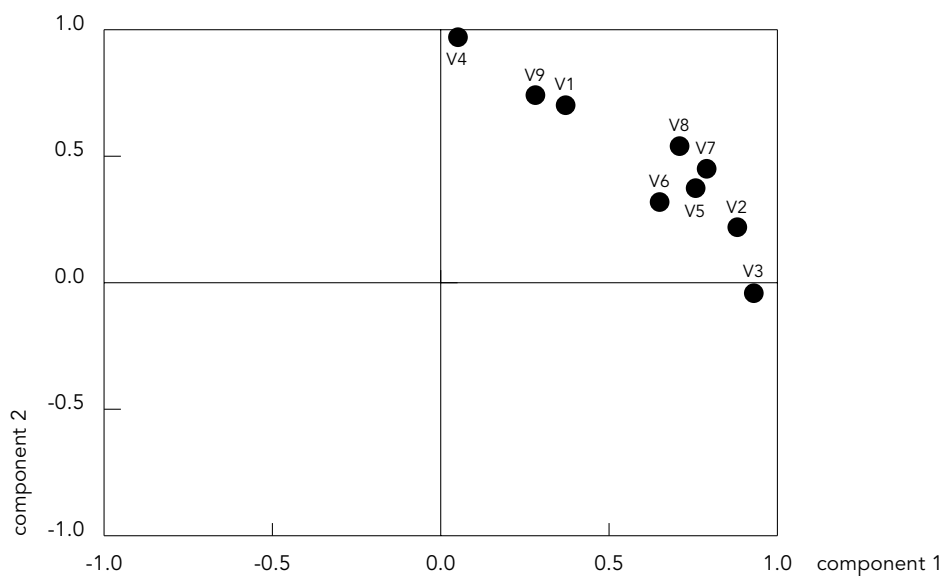

V1 - pesticides sales

V2 - testicular cancer hospitalization rates (0-14 yr. old)

V3 - testicular cancer hospitalization rates (15-49 yr. old)

V4 - sperm evaluation rates

V5 - testicular cancer chemotherapy rates

V6 - histerosalpingography rates

V7 - breast cancer mortality rates

V8 - ovarian cancer mortality rates

V9 - orchydopexy rates

distribution, the long term effect of a cumulative exposure process manifested by higher mortality rates in older age strata in the analyzed regions. These observations may be considered in agreement with a possible association between pesticide exposure and breast cancer incidence, mainly after menopause, considering the estrogen-like chemical struc- 
ture displayed by some of them which hypothetically would allow them to bind into hormonal receptors, thus acting as endocrine disruptors. The elevated observed correlation between pesticides sales with ovarian cancer, also a hormonal dependent tumor site $(r=0.71$, 95\%CI: 0.19-92) may be potentially considered in support for the same exposure (estrogenlike chemicals) association.

Unavailability of testicular cancer incidence in the majority of the studied states yielded us to try to estimate it towards the ascertainment of testicular cancer hospitalization rates, authorized chemotherapy rates and testis cancer mortality rates. Moderate correlation coefficients were observed for these indicators and pesticide sales (Table 3 ). In the same direction, cryptorchidism, a risk factor to testicular cancer, also revealed moderate correlation between its corrective surgery rates and pesticides sales, despite a lack of statistical significance (Table 3).

Sperm evaluation, a prior routine exam on infertility causes exploration, showed elevated correlation with pesticide consumption too ( $r=0.60$, 95\%CI: -0.01-0.88). However, similar correlation magnitude was not seen for histerosalpingography rates $(r=0.21)$.

Testis has been indeed pointed out in the literature as a possible target organ for endocrine disruptors, and as a whole, the results observed in this study are in accordance with these remarks. In support of this, a more detailed search for testicular hazard indicators was carried out in the State of Rio Grande do Sul, which showed an estimated testis cancer hospitalization rate of 6.4 per 100.000 among men 15-49 yr., several folds higher than in other Brazilian states (Table 1). This search included the estimation of testicular cancer hospitalization rates and sperm evaluation rates in the different municipalities of Rio Grande do Sul (Table 4 ). We could observe higher than expected rates (according to similar indicators in other states) for several municipalities with important agriculture (corn, wheat, tobacco, rice, soy, among others) and cattle related activities, all of them with presumably high exposure levels to pesticides.

Very high sperm evaluation rates were also seen in the 90's at several municipalities in the State of São Paulo, wherein the highest amount of pesticides sales was carried out in Brazil in 1985 (about 44 thousand tons). Among them, can be highlighted São José do Rio Preto (533.5/100.000 men), Marília (505.5), Campinas (415.1), Ribeirão Preto (363.6), Araçatuba (324.0), Bauru (291.3), Araraquara (267.0), Reg- istro (186.3) and Presidente Prudente (175.8), all of them surrounded by intensive crop areas such as sugarcane, corn, citrics, soy, corn and other cultures in which pesticides are commonly spread.

The correlation coefficient between corn production volume in Marília, Presidente Prudente, Bauru, Araçatuba, São Jose do Rio Preto, Campinas and Registro agrarian districts in 1991-1992 (Anuário Estatistico do Estado de São Paulo, 1992) and sperm evaluation rates (1999-2000) was $r=0.87\left(r^{2}=0.80,95 \%\right.$ CI: 0.43 0.98 ). For sugarcane production in the same years, the correlation coefficient was $\mathrm{r}=0.47$ $\left(\mathrm{r}^{2}=0.22\right)$.

Even considering that such crop areas have a higher geographical distribution than the main cities in which they are settled and wherein sperm evaluation were ascertained, the observed correlation pattern is worth highlighting. Despite the fact that pesticide exposure related to agriculture cultures poses higher risks to those occupationally exposed, it possibly suggests as an environmental marker to closer population groups as a consequence of food chain, water supplies and even airborne contamination (Heindel et al., 1994). These results seems to support the hypothesis that some human reproductive hazards such as those here analyzed (cryptorchidism, infertility, breast, testis, prostate and ovarian cancer) may also result from such environmental exposures, whether the hormonal-like chemical structure shared by certain chemicals could allow them to mimic the natural hormonal activity.

Despite the observed correlations presented here, it should be worth paying attention to other environmentally related risk factors which could also be contributing to such endpoints. Hence, it is important to mention the international warnings on the current practices related to hormone addition in food supplies offered in cattle and poultry farming aimed at obtaining larger animals in shorter time, besides the observation of pesticide residuals in the same food supplies (Maghuin-Rogister, 1995; McEwen \& McNab, 1997; Meyer, 2001; Schmidely, 1993). In Brazil, population distribution of animal protein intake has been rising in the last decades, mainly as a consequence of a rise on poultry meat intake (Monteiro et al., 2000), and this changing diet pattern could theoretically represent an additional source of exposure to endocrine disrupter chemicals.

Finally, a principal components and a factor analysis were carried out aimed at exploring the possible hidden and unknown relationships among pesticides sales and the studied 
reproductive variables. In this sense, both were developed as an additional procedure to explore the relationships of interest in this investigation in a multivariate approach.

The first enabled us to identify two components which explained more than $72 \%$ of all variance observed with these variables. After rotating the obtained factor matrix, and analyzing the variables joining each one of the components, we interpreted them in the following way: considering that the first component displays high factor loading to testicular cancer hospitalizations, testicular cancer chemotherapy, breast cancer mortality, ovarian cancer mortality, and moderate loading for pesticides sales and histerosalpingography performed rates, we named it as a cancer related component. The second one, joining high loading factors to sperm evaluation rates and orchidopexy rates, we named it as an infertility related component. It is worth noting that pesticides sales share moderate contributions with both components (cancer-related and infertility-related), therefore possibly adding some support for their involvement on such reproductive system hazards.

Overall, and even taking into account the validity weaknesses previously commented according to the used variables, a comprehensive evaluation of all presented results in this study could be interpreted as suggestive for an im- portant role of pesticides diffusion in Brazil and the further development of reproductive disturbances affecting the population regardless of gender, and in a wide age spectrum in short and medium time interval. If true, repercussions of such exposure will probably present a more intensive pattern of reproductive disturbances in the near future, considering that pesticides sales in Brazil, mainly herbicides and insecticides, have been continuously increasing since the eighties.

\section{Conclusions}

An ecological study in 11 States of Brazil analyzed the volume of pesticide sales in 1985 and the respective indicators of selected human reproductive disorders observed in the 1990s. Moderate-to-high Pearson correlation coefficients were observed for breast cancer mortality (mainly among women 50-69 years of age in 1995-1997), ovarian cancer mortality, prostate cancer mortality, testicular cancer hospitalization rates, and spermiogram rates, the latter mainly in certain rural areas with intensive agricultural activity. The results suggest that population exposure to pesticides in the 1980s in some Brazilian States may have been associated with selected reproductive disorders observed a decade later.

\section{References}

AL-OMAR, M. A.; ABBAS, A. K. \& AL-OBAIDY, A. S., 2000. Combined effect of exposure to lead and chlordane on the testicular tissues of swiss mice. Toxicology Letters, 115:1-8.

BULLMAN, T. A.; WATANABE, K. K. \& KANG, H. K., 1994. Risk of testicular cancer associated with surrogate measures of Agent Orange exposure among Vietnam veterans on the Agent Orange Registry. Annals of Epidemiology, 4:11-16.

CARLSEN, E.; GIWERCKMAN, A.; KEIDING, N. \& SKAKKEBAEK, N. E., 1992. Evidence for decreasing quality of semen during past 50 years. $B M J$, 305:609-613.

CARLSEN, E.; GIWERCKMAN, A.; KEIDING, N. \& SKAKKEBAEK, N. E., 1993. Evidence for increasing incidence for abnormalities in the human testis: A review. Environmental Health Perspectives, 101(Sup. 2):65-71. 
CHAPIN, R. E.; STEVENS, J. T.; HUGHES, C. L.; KELCE, W. R.; HESS, R. A. \& DASTON, G. P., 1996. Endocrine modulation of reproduction. Fundamental and Applied Toxicology, 29:1-17.

CHIA, S. E., 2000. Endocrine disruptors and male reproductive function-a short review. International Journal of Andrology, 23(Sup. 2):45-46.

CHILVERS, C.; DUDLEY, N. E.; GOUGH, M. H.; JACKSON, M. B. \& PIKE, M. C., 1986. Undescended testis: The effect of treatment on subsequent risk of subfertility and malignancy. Journal of Pediatric Surgery, 21:691-696.

CLEGG, E. D.; SAKAI, C. S. \& VOYTEK, P. E., 1986. Assessment of reproductive risks. Biology of Reproduction, 34:5-16.

DOLAPSAKIS, G.; ULACHONIKOLIS, J. G.; VARVERISC, C. \& TSATSAKIS, A. M., 2001. Mamographic findings and occupational exposure to pesticides currently in use in Crete. European Journal of Cancer, 30:1531-1536.

EKBOM, A.; WICKLUND-GLYNN, A. \& ADAMI, H. O., 1996. DDT and testicular cancer. Lancet, 347:553554.

FLEMING, L. E.; BEAN, J. A.; RUDOLPH, M. \& HAMILTON, K., 1999. Cancer incidence in a cohort of licensed pesticide applicators in Florida. Journal of Occupational and Environmental Medicine, 41:279-288.

GARCIA, E. G. \& ALMEIDA, W. F., 1991. Exposição dos trabalhadores rurais aos agrotóxicos no Brasil. Revista Brasileira de Saúde Ocupacional, 72:7-11.

GLASS, R. I.; LYNESS, R. N.; MENGLE, D. C.; POWELL, K. E. \& KAHN, E., 1979. Sperm count depression in pesticide applicators exposed to dibromochloropropane. American Journal of Epidemiology, 109: 346-351.

GOLDSMITH, J. R., 1997. Dibromochloropropane: Epidemiological findings and current questions. Annals of the New York Academy of Sciences, 837:300-306.

GRAY Jr., L. E., 1998. Xenoendocrine disrupters: Laboratory studies on male reproductive effects. Toxicology Letters, 102-103:331-335.

HEINDEL, J. J.; CHAPIN, R. E.; GULATI, D. K.; GEORGE, J. D.; PRICE, C. J.; MARR, M. C.; MYERS, C. B.; BARNES, L. H.; FAIL, P. A.; GRIZZLE, T. B. et al., 1994. Assessment of the reproductive and developmental toxicity of pesticide/fertilizer mixtures based on confirmed pesticide contamination in California and Iowa groundwater. Fundamental and Applied Toxicology, 22:605-621.

HENRIKSEN, G. L.; MICHALEK, J. E.; SWABY, J. A. \& RAHE, A. J., 1996. Serum dioxin, testosterone, and gonadotropins in veterans of Operation Ranch Hand. Epidemiology, 7:352-357.

IRVINE, D. S., 2000. Male reproductive health: Cause for concern? Andrologia, 32:195-208.

JOFFE, M., 2001. Are problems with male reproductive health caused by endocrine disruption? $O c$ cupational \& Environmental Medicine, 58:281288.

JONES, A. R. \& COOPER, T. G., 1999. A re-appraisal of the post-testicular action and toxicity of chlorinated antifertility compounds. International Journal of Andrology, 22:130-138.

LAHDETIE, J., 1995. Occupation-and exposure-relat- ed studies on human sperm. Journal of Occupational and Environmental Medicine, 37:922-930.

LIPSHULTZ, L. I.; ROSS, C. E.; WHORTON, D.; MILBY, T.; SMITH, R. \& JOYNER, R. E., 1980. Dibromochloropropane and its effect on testicular function in man. Journal of Urology, 124:464-468.

MAGHUIN-ROGISTER, G., 1995. The use of anabolic hormones and growth promoters in meat production and its consequence to man. Journal de Pharmacie de Belgique, 50:455-460.

MAPA (Ministério da Agricultura, Pecuária e Abastecimento), 2000. Meios de Produção. Tabela 1.6: Defensivos Agrícolas. Vendas por Categoria. Junho de $2001<$ http://www.agricultura.gov.br/spa/pagespa/ ch01/vendfag.xls $>$.

McEWEN, S. A. \& McNAB, W. B., 1997. Contaminants of non-biological origin in foods from animals. Revue Scientifique et Technique, 16:684-693.

MEYER, H. H., 2001. Biochemistry and physiology of anabolic hormones used for improvement of meat production. APMIS, 109:1-8.

MILLS, P. K., 1998. Correlation analysis of pesticide use data and cancer incidence rates in California counties. Archives of Environmental Health, 53:410-413.

MONOSSON, E.; KELCE, W. R.; LAMBRIGHT, C.; OSTBY, J. \& GRAY Jr., L. E., 1999. Peripubertal exposure to the antiandrogenic fungicide, vinclozolin, delays puberty, inhibits the development of androgen-dependent tissues, and alters androgen receptor function in the male rat. Toxicology and Industrial Health, 15:65-79.

MONTEIRO, C. A.; MONDINI, L. \& COSTA, R. B. L., 2000. Mudanças na composição e adequação nutricional da dieta familiar nas áreas metropolitanas do Brasil (1988-96). Revista de Saúde Pública, 34:251-25.

PADUNGTOD, C.; LASLEY, B. L.; CHRISTIANI, D. C.; RYAN, L. M. \& XU, X., 1998. Reproductive hormone profile among pesticide factory workers. Journal of Occupational and Environmental Medicine, 40:1038-1047.

PETRELLI, G.; FIGA-TALAMANCA, I.; TROPEANO, R.; TANGUCCI, M.; CINI, C.; AQUILANI, S.; GASPERINI, L. \& MELI, P., 2000. Reproductive male-mediated risk: Spontaneous abortion among wives of pesticide applicators. European Journal of Epidemiology, 16:391-393.

POTASHNIK, G. \& PORATH, A., 1995. Dibromochloropropane (DBCP): A 17-year reassessment of testicular function and reproductive performance. Journal of Occupational and Environmental Medicine, 37:1287-1292.

PUTNAM, S. D.; CERHAN, J. R.; PARKER, A. S.; BIANCHI, G. D.; WALLACE, R. B.; CANTOR, K. P. \& LUNCH, C. F., 2000. Lifestyle and anthropometric risk factors for prostate cancer in a cohort of Iowa men. Annals of Epidemiology, 10:361-369.

RESTREPO, M.; MUÑOZ, N.; DAY, N. E.; PARRA, J. E.; de ROMERO, L. \& NGUYEN-DINH, X., 1990. Prevalence of adverse reproductive outcomes in a population occupationally exposed to pesticides in Colombia. Scandinavian Journal of Work, Environment \& Health, 16:232-238.

RESTREPO, M.; MUÑOZ, N.; DAY, N.; PARRA, J. E.; HERNANDEZ, C.; BLETTNER, M. \& GIRALDO, A., 
1990. Birth defects among children born to a population occupationally exposed to pesticides in Colombia. Scandinavian Journal of Work, Environment \& Health, 16:239-246.

RODRIGUEZ, H. \& BUSTOS-OBREGON, E., 2000. An in vitro model to evaluate the effect of an organophosphori agropesticide on cell proliferation in mouse seminiferous tubules. Andrologia, 32:1-5.

SAFE, S. H., 2000. Endocrine disruptors and human health-is there a problem? An update. Environmental Health Perspectives, 108:487-493.

SARACCI, R.; KOGEVINAS, M.; BERTAZZI, P. A.; BUENO-DE-MESQUITA, B. H.; COGGON, D.; GREEN, L. M.; KAUPINNEN, T.; L'ABBE, K. A.; LITTORIN, M.; LYNGE, E. et al., 1991. Cancer mortality in workers exposed to chlorophenoxy herbicides and chlorophenols. Lancet, 338:1027-1032.

SCHARPE, R. M., 2001. Hormones and testes development and the possible adverse effects of environmental chemicals. Toxicology Letters, 120:221232.

SCHMIDELY, P., 1993. Quantitative bibliographic review on the use of anabolic hormones with steroidogenic action in ruminants for meat production. II. Principal mode of action. Reproduction, Nutrition, Development, 33:297-323.

SEGI, M., 1960. Cancer Mortality for Selected Sites in 24 Countries (1950-57). Sendai: Department of Public Health, Tohoko University School of Medicine.
STELLMAN, S. D.; DJORDJEVIC, M. V.; MUSCAT, J. E.; GONG, L.; BERNSTEIN, D.; CITRON, M. L.; WHITE, A.; KEMENY, M.; BUSCH, E. \& NAFZIGER, N. A., Relative abundance of organochlorine pesticides and polychlorinated biphenyls in adipose tissue and serum of women in Long Island, New York. Cancer Epidemiology, Biomarkers \& Prevention, 7:489-496

TEITELBAUM, D. T., 1999. The toxicology of 1,2-dibromo-3-chloropropane (DBCP): A brief review. International Journal of Occupational and Environmental Health, 5:122-126.

WEIR, H. K.; MARRETT, L. D.; KREIGER, N.; DARLINGTON, G. A. \& SUGAR, L., 2000. Pre-natal and peri-natal exposures and risk of testicular germcell cancer. International Journal of Cancer, 87: 438-443.

WESSELING, C.; ANTICH, D.; HOGSTEDT, C.; RODRIGUEZ, A. C. \& AHLBOM, A., 1999. Geographical differences of cancer in Costa Rica in relation to environmental and occupational pesticide exposure. International Journal of Epidemiology, 28:365-374.

WIKLUND, K.; DICH, J.; HOLM, L. E. \& EKLUND, G., 1989. Risk of cancer in pesticide applicators in Swedish agriculture. British Journal of Industrial Medicine, 46:809-814.

ZAHM, S. H. \& BLAIR, A., 1993. Cancer among migrant and seasonal farmworkers: An epidemiologic review and research agenda. American Journal of Industrial Medicine, 24:753-766.

Submitted on 24 August 2001

Final version resubmitted on 6 December 2001

Approved on 14 December 2001 